QS А. Грённ и О. Клонова (ред.) Русский язык в контрастивном аспекте, Oslo Studies in Language 2(3), 2010. 619-639. (ISSN 1890-9639)

http://www.journals.uio.no/osla

\title{
РОЛЬ ЭМПАТЕМ ПРИ ПЕРЕВОДЕ НОРВЕЖСКОЙ ПРОЗЫ НА РУССКИЙ ЯЗЫК
}

\author{
ОльгА ЯныгинА \\ Мурманский государственный технический университет
}

\section{АннотАция}

В статье рассматривается роль эмпатем в передаче имплицитных эмотивных компонентов при переводе норвежской прозы на русский язык. В центре внимания находятся лексические и синтаксические средства, используемые профессиональными и непрофессиональными переводчиками. Согласно результатам исследования, русскоязычные переводы изобилуют эмотивной лексикой и эмфатическими синтаксическими конструкциями, тогда как норвежский оригинал кажется лишенным какойлибо эксплицитно выраженной эмоции. Таким образом, в процессе перевода с норвежского на русский переводчиками были привнесены (намеренно или ненамеренно) некоторые дополнительные коннотативные смыслы. Этот факт объясняется культурными и языковыми различиями, т.к. в славянских языках эмоции выражаются гораздо более эксплицитно. Переводчик, воспринимая эмпатемы, присутствующие в эмотивном тексте, обязан сохранить имплицитную эмоциональность и обычно делает это в эксплицитной форме.

\section{[1] ВВЕДЕНИЕ}

Толчком к написанию данной работы послужил почти полугодовой опыт преподавания русского языка и чтения курса лекций по проблемам понимания и передачи глубинных уровней смысла, имплицитной (вербально невыраженной, скрытой, подтекстовой) информации для магистратуры университета Осло в 2008 году в рамках настоящего проекта RuN.

Особенно при сравнении переводных текстов с их оригиналами на норвежском языке в процессе создания учебного пособия для изучающих русский язык нельзя было не заметить различий на эмоциональном уровне.

Нас заинтересовала содержательная сторона действий переводчика. Было не совсем ясно, каким образом переводчик приходит к таким вариантам перевода, которые не подтверждаются прямыми ссылками на словарные значения, - есть ли это результат интуиции, не подлежащий формальному объяснению, или же существует объективная процедура (модель, алгоритм и т.п.). Одним из возможных направлений поиска ответа на этот вопрос, как пред- 
ставляется, может стать изучение проблемы понимания и передачи глубинных уровней смысла, имплицитной информации.

В процессе восприятия текста в сознании переводчика возникают особые когнитивные комплексы, объединяющие различные единицы психической деятельности - представления, оценки, выводы. Содержание этих комплексов осознается переводчиком как наиболее яркие контентные свойства текста, ассоциирующиеся с мироощущениями автора и его персонажей. Сформированные комплексы такого рода предлагается называть эмпатемами (Гусев 2005).

Функционально-коммуникативный подход к анализу художественного текста и его перевода (также используется термин «системно-деятельностный подход») опирается на тезисы: 1) за каждым текстом стоит его творец, автор, уникальная языковая личность; 2) каждый текст опрокинут в социум, направлен к адресату, читателю.

При таком подходе выделяются динамические текстовые единицы, имеющие лингвистическую и экстралингвистическую сущности, различающиеся функционально и коммуникативно. Вслед за Болотнова (1992) мы также рассматриваем эмоциональный подуровень прагматики как очень важный и перспективный. Его четкая проработка и нахождение эквивалентов на языке перевода представляют собой процедуру так называемого эмпатического анализа.

Эмпатия как психологическая проблема уже давно привлекает интерес ученых (начиная с В. Дильтея, Э. Титченера, К. Ясперса, Т. Липпса и др. ). Приведем определение, предложенное Н. И. Сарджвеладзе: «Эмпатия - это особый психический акт, по своей природе - целостное образование когнитивных, эмоциональных и моторных компонентов, которое включено в качестве особой формы психического контакта в социальное взаимодействие между людьми» (Сарджвеладзе 1978, 485).

\section{[2] ЭМПАТЕМЫ В ПРОЦЕССЕ ВОСПРИЯТИЯ ТЕКСТА}

\section{[2.1] Эмотивное пространство текста}

Взаимодействие эмпатем, репрезентирующих исходную (автор) и конечную (читатель) точки переводческого акта, является одним из ключевых моментов перевода. Одним из конкретных способов активизации познавательных (когнитивных) функций сознания является эмпатический анализ - осмысление на основе отождествления себя с объектом эмпатии. Применительно к переводу мы рассматриваем эмпатический анализ как набор операций, которые происходят в сознании реципиента (в данном случае - переводчика) при активном и углубленном осмыслении содержательных категорий текста, ассоциирующихся с 1) мироощущением и мировосприятием реального или вымышленного субъекта (автора, персонажа), репрезентированного в тексте 
оригинала и 2) реакцией конечного реципиента (читателя) на текст, созданный переводчиком.

Бабенко \& Казарин (2005) представили принципиально новый подход к художественному тексту. В частности, ими подробно рассматривается эмотивное пространство текста и его анализ, эмотивно-психологические смысльь в структуре образов персонажей и эмотивные смысль в структуре образа авmopa.

В настоящей статье предпринимается попытка описания системы эмотем и эмоционального тона в произведениях на норвежском языке и их перевода на русский язык с включением эмпатем как неотъемлемой части переводческого процесса. Как представляется, роман «Naiv. Super» известного норвежского прозаика Эрленда Лу, а также его перевод на русский язык, сделанный Инной Стребловой ${ }^{1}$, является достаточно интересным с точки зрения эмпатического проникновения в эмоциональный мир персонажа. Для целей нашего исследования очень важна эмоционально-оценочная позиция автора художественного текста, средства ее выражения в оригинальном тексте и возможность ее сохранения при переводе. В исследование были также включены тексты переводов отдельных фраз, сделанные участниками проекта RuN, проводимом в настоящее время университетом Осло. Для удобства этот вариант перевода будем выделять курсивом.

\section{[2.2] Имплицитный смысл высказывания}

Известный переводческий вопрос: что переводить - слова или скрываемый ими смысл, «дух», - наиболее ярко проявляется при необходимости передать в переводе подразумеваемый имплицитный смысл высказывания. Проблема имплицитности и попытки ее решения как нельзя лучше демонстрируют тесную взаимосвязь переводоведения и лингвистики. К общелингвистическим вопросам, возникающим при исследовании имплицитного смысла, относятся формирование и структура имплицитного смысла высказывания, отношение имплицитного смысла к пресуппозициям высказывания и подтексту текста, терминологические вопросы обозначения имплицитности отдельного высказывания. Собственно переводческие проблемы касаются установления способов передачи имплицитного смысла в процессе перевода и определения причин подобных переводческих действий.

Устоявшимся лингвистическим фактом является то, что смысл высказывания превосходит суммарный набор языковых значений, входящих в высказывание слов (Комиссаров 1999, 49). Этот смысл складывается из взаимодействия актуализированных значений составных единиц высказывания и концептуальной картины мира когнитивной сферы коммуникантов, включающей знания языка, ситуации и окружающего мира (фоновые знания). Поэтому

\footnotetext{
${ }^{1}$ Эрленд Лу. Наивно. Супер. СПб. 2004.
} 
образование смысла, согласно теории релевантности, есть его выведение или интерпретация. Смысловая структура высказывания образуется выраженным (языковые значения слов) и невыраженным (имплицитным) уровнями. Имплицитный смысл является атрибутом любого высказывания в вербальной коммуникации.

При сопоставлении двух языков в процессе перевода к имплицитному смыслу высказывания, дополнительно к указанным компонентам, относятся и части смысловой структуры высказывания, недоступные для выведения и понимания рецепторами перевода даже в случае вполне адекватной передачи языкового содержания (эксплицитного смысла). Языковое содержание оригинала и перевода может различаться по степени выраженности семантических компонентов, т.е. по степени экспликации в высказывании частей когнитивной среды. Эти различия в степени выраженности компонентов когнитивной среды диктуются нормами каждого из языков. Вместе с тем, учитывая определенную универсальность когнитивного пространства, можно предположить, что разность используемых средств не будет радикальной (Красных 1999, 119).

\section{[2.3] Прагматическая адаптация при переводе}

Переводческие проблемы возникают в связи с тем, что передача языкового содержания не дает возможности рецепторам перевода вывести подразумеваемый смысл. В результате приходится добавлять информацию или заменять часть содержания, чтобы были понятны как языковое содержание, так и эмотивный смысл оригинала в языке перевода. Зачастую, ввиду отсутствия пресуппозиций у получателей перевода, необходимо проводить прагматическую адаптацию, например, добавлять информацию (в том числе и эмоциональную), с тем чтобы была понятна вторая часть смысла высказывания, конкретно-контекстуальный смысл, где содержатся знания о конкретной ситуации и намерениях автора и таким образом дать возможность рецептору понять мысль, «спрятанную» за стимулом, т.е. дать возможность вывести импликатуру.

Каждая из частей имплицитного смысла высказывания оказывает свое влияние на процесс перевода. Хотя переводчики имеют дело с целым имплицитным смыслом высказывания, соотношение выраженного и подразумеваемого смысла неодинаково при передаче разных видов имплицитности. Переводчик решает, какие части имплицитного смысла высказывания в переводе необходимо эксплицировать, а какие можно сохранить невыраженными. Это связано с решением вопроса, какие части когнитивной среды рецепторов перевода должно привлекать высказывание и какие языковые средства для этого нужно использовать. Переводчик делает этот вывод, основываясь на своих знаниях о структуре смысла высказывания в принимающей культуре и ис- 
ходя из своих представлений о способности рецепторов перевода извлечь искомый подразумеваемый смысл (Кашичкин 2004, 75-81).

\section{[2.4] Эмоционально-смысловая доминанта}

Эмоциональная тональность текста и средства ее создания на языке оригинала очень важны при анализе переводческих решений: насколько удалось сохранить при переводе эмоционально-смысловую доминанту текста. Под эмоционально-смысловой доминантой понимается «система когнитивных и эмотивных эталонов, характерных для определенного типа личности и служащих психической основой метафоризации и вербализации картины мира в тексте» (Белянин 2000, 57).

\section{[2.5] Национальная специфика вербального поведения}

Национальная языковая картина мира и своеобразие лингвистического фонда определенного культурно-языкового сообщества взаимосвязаны, влияние культуры на язык не вызывает сомнения. Присущие каждому обществу особый взгляд на мир и определенная система ценностей находят свое выражение в его языке. Тексты художественных произведений, написанные на разных языках, могут служить средством познания речевого поведения носителей данных языков.

Ю. А. Сорокин отмечает, что «художественная литература, принадлежащая той или иной локальной культуре, приобретает определенный интерес в силу различий вербального (речевого, кинесического и эмотивного) поведения, отличающего одну локальную культуру от другой, и может служить одним из источников культурологических сопоставлений, помогающих выявлять специфику вербального поведения» (Сорокин 1977, 122-123). Следует сказать, что текст перевода ни в коем случае не копирует лингвистические особенности оригинального художественного текста, а представляет собой определенную интерпретацию языковых и культурных феноменов текста оригинала. Ю. А. Сорокин указывает на важность учета национальной специфики при переводе художественных произведений: «Художественный перевод, не учитывающий специфических для каждой локальной культуры способов интерпретации, не только не дает представления об образной логике того или иного текста, но, как правило, искажает ее, давая читателю неверное представление о художественном мышлении, присущем той или иной культуре» (Сорокин 1977, 123).

Естественно, что для современных лингвистических исследований, в том числе и в сфере сопоставительной лингвистики, характерно обращение к текстам художественных произведений с целью исследования языкового материала. Это обусловлено тем, что художественный текст отражает набор языковых и экстралингвистических правил, знакомых носителю данных языка 
и культуры. Таким образом, исследование художественных текстов в оригинальных и переводных вариантах позволяет выявлять особенности идиостиля автора на языке оригинала и перевода и устанавливать характерные семантические особенности языковых средств, используемых в произведениях одного и того же автора на двух языках.

На стадии сопоставления эмпатем двух типов, ассоциирующихся в сознании переводчика с принципиально разными языковыми личностями: иноязычной - автора, и русскоязычной - читателя, сталкиваются «языковые картины мира», которые не только включают в себя цели и установки носителей разных языков, но и фиксируют способы отображения ими действительности.

Можно отметить, что системе эмотивных лексических средств в разных языках присуща ярко выраженная специфичность. Это обусловлено тем, что «сфера эмоциональных проявлений обладает явно наблюдаемым национальным колоритом» (Мезенцева 2006, 354-357). Так, переводоведы уже обращали внимание на сдержанность, эмоциональную «приглушенность» английской языковой личности, в частности, С. Флорин писал: «Очевидно, англосаксы восклицают тише, удивляются, волнуются, возмущаются и ликуют спокойнее славян» (Флорин 1983, 76). Можно отметить также, что в русском языке коммуникативная установка убеждения достигается с помощью риторического пафоса, возвышенного и торжественного тона изложения. Для достижения этого стилистического эффекта применяется широкий набор языковых средств, в том числе книжная лексика, большое число определителей, эмоционально насыщенные слова, развернутые сложносочиненные предложения, всевозможные фигуры речи и эмфатические конструкции.

\section{[2.6] Эмоциональная составляющая текста и ее интерпретация при переводе}

В переводе при передаче экспрессивной функции ставится задача достижения экспрессивного эквивалента, т.е. создания в процессе межъязыкового общения такой ситуации, при которой эмоциональная реакция реципиента текста перевода могла бы соответствовать эмоциональной реакции реципиента текста оригинала. Сама процедура поиска представляет собой интуитивный подбор гипотез и их отклонения на основе тщательного анализа неоднозначных мест текста, создающих стилистическую напряженность, его эмоциональную тональность.

Во-первых, следует определить, что такое эмотивный текст. Одна из трудностей определения эмотивного текста состоит в том, что в его плане выражения и в поверхностном содержании могут отсутствовать формальные эмоциональные знаки - в то время как все смысловое пространство текста может служить символом переживаемых эмоций, т. е. быть глубинно, имплицитно эмотивным. Бабенко \& Казарин (2005) убедительно показали, что функцио- 
нально эмотивный текст транслирует эмоции на адресата. Для такого текста главное - выразить их так, чтобы адресат осознал этот информационный фокус. Поэтому полагаем, что эмотивный текст - это прежде всего текст для адекватного восприятия и понимания эмоционального содержания. Один из постулатов, выдвигаемых в их работе, звучит следующим образом: читатель имеет право на собственную интерпретацию смысла художественного текста. Эта интерпретация зависит не только от текста, но и от психологических особенностей читателя (Бабенко \& Казарин 2005, 373).

Художественный текст обладает множественностью интерпретаций в силу различных способов восприятия текста автором и читателем (Ананьина $2009,343)$. Нахождение адекватных способов актуализации эмпатем, включающих инокультурную информацию, зависит от того, насколько переводчик владеет речью и может прогнозировать реакцию читателя на текст перевода. Нельзя забывать, что, когда речь идет о переводе, его читатели реагируют на способы описания инокультурного феномена, соотнося их с тем, как тот представлен в их культурно-языковой среде, иначе неизбежно «отторжение» текста.

В эмпатемах отдельных норвежских авторов (например, в романе Эрленда Лу «Наивно. Супер») зачастую отражается отстраненность и сдержанность эмоциональных проявлений. Очевидно, норвежскими читателями авторская отстраненность, недосказанность будет восприниматься как нормативный способ отображения событий, а русскими - как эмоциональная «недосказанность». Мы полагаем, что для этих случаев применима мысль Я. И. Рецкера о том, что «русский язык не терпит 'вакуума', неполноты, незаконченности мысли» (Рецкер 1974, 141). Подобные расхождения проявляются в особенностях речи как двух способов формирования и формулирования мысли посредством языка, характерных для носителей разных языков.

Ментальные пространства индивидов никогда не совпадают и определяются индивидуальными знаниями, но они, репрезентируясь индивидуальным «вербальным кодом», по мнению Т. А. Фесенко, могут иметь «общие зоны» (Фесенко 2005, 32-35), которые предопределяют степень достоверности перевода, и перевод будет тем успешнее, чем шире зоны пересечения индивидуальных ментальных пространств автора и переводчика.

Наряду с высокой степенью достоверности перевода существует упрощенное перекодирование и творческие отклонения. Упрощенное перекодирование оригинала обусловлено, по мнению Ю. А. Сорокина, эмотивной и когитивно-когнитивной дистанцией между переводчиком и автором. Если дистанция велика, то оказываются непрозрачными все те глубинные, как правило, конфликтные, ситуации, на которые указывает исходная текстовая фактура. Ориентация на массового читателя и требования массовой культуры перевод- 
ного языка приводят к устранению непривычных стилистических приемов (Сорокин 2005, 46).

\section{[3] ЭМОЦИОГЕННЫЕ СИТУАЦИИ В ТЕКСТЕ}

\section{[3.1] Эмоции персонажа}

Художественный текст воздействует на читателя совокупностью всех своих формально-семантических качеств и свойств (системой образов, сюжетом, композицией и др.), единой совокупностью языковых средств, в составе которой лексические средства занимают не последнее место. По данным многих психологов, вся теория заражения связана с явлением индукции эмоционального воздействия, основанном на сильном воздействии фрагментов, содержащих лексику эмоций. Ткань художественного произведения неравноценна по силе эмоционального воздействия, это зависит чаще всего от наличия в тексте эмотивной лексики. В тексте выделяются фрагменты, изображающие так называемые эмоциогенные ситуации, которые обладают повышенным уровнем эмотивного воздействия.

Возьмем, к примеру, несколько текстовых фрагментов, рисующих в своей целостности эмоциональное состояние главного героя. Первый контекст представляет описание игры в крикет с братом. Фразы, содержащие лексические сигналы его внутренней речи, как правило, имитирующими своеобразный «поток сознания», торопливо и увлеченно, как бы «взахлеб» раскрывающими внутренний мир персонажа, являются особенно значимыми и требуют большого переводческого мастерства:

(1) a. Og hvis jeg bommet, hadde jeg ryggen fri, fordi han ennå ikke hadde fullført runden. Alt det kunne jeg bare glemme. Jeg hadde bommet en gang for mye. Nå skulle jeg snart slå. Dette skulle gå bra: Jeg var overbevist om at det var et spørsmål om sekunder før jeg var ovenpå igjen.

б. Если бы я промахнулся, это мне ничем не грозило, потому что он еще не прошел до конца весь круг. Теперь все эти надежды растаяли. Я не рассчитал и допустил решающий промах. Ничего, сейчас мой черед бить. Вот так должно получиться! Я был совершенно уверен, что скоро опять вырвусь вперед, что это вопрос нескольких секунд.

в. А промахнусь - тыл у меня все равно обеспечен, ведь он еще не завершил круг. Но все это можно было забыть. Я промахнулся на раз больше. Скоро мне бить. Все должно было получиться. Я был убежден в том, что это вопрос нескольких секунд и я снова поведу.

Этот фрагмент, и в оригинале, и в первом варианте перевода, как видим, насыщен эмотивной лексикой, передающей взволнованность, спортивный азарт 
и эмоциональность персонажа. Второй вариант менее удачен с точки зрения эмотивного содержания.

В то же время экспрессивные номинации вызывают у читателя не только сочувствие переживаниям главного героя, но и мягкую иронию, смех, которые обнаруживает и сам автор по отношению к своему персонажу. Этот диссонанс еще более ощущается при восприятии следующего текстового фрагмента, в котором главный герой после ссоры с братом невольно расплакался:

(2) a. Jeg beskyldte ham for juks og vi leste i reglene og kranglet videre. Jeg sa et par ting som var helt på kanten. Til slutt spurte min bror om det var noe i veien. Hva er det med deg? sa han. Jeg var på vei til å si at det ikke var noe, men så kjente jeg at alt veltet opp i meg. Det var overveldende og ekkelt. Jeg har aldri kjent noe lignende og jeg klarte ikke å si noe. I stedet satte jeg meg på gresset og ristet på hodet. Min bror kom og satte seg ved siden av meg. Jeg begynte å gråte. Det var årevis siden jeg hadde grått. Det må ha vært overraskende for min bror.

б. Я придрался и стал говорить, что он сжульничал, мы перечитали правила и снова заспорили. При этом я договаривался до совершенно диких вещей. Кончилось тем, что брат стал спрашивать, в чем дело. - Что это на тебя нашло? - спросил он меня. Я уже собирался ответить, что ничего особенного, как вдруг что-то во мне перевернулось, и тут на меня нахлынуло все сразу. Это было мерзко и непреодолимо. Я никогда ничего подобного не испытывал и сейчас не мог выговорить ни слова. Я только сел на траву и потряс головой. Брат подошел ко мне и опустился рядом. Я расплакался. Прошло, наверное, несколько лет с тех пор, как я в последний раз плакал. Брат растерялся от неожиданности.

в. Я Ябвинил его в жульничестве, мы почитали правила и продолжили ругаться. Я сказал ему пару не вполне приемлемых вещей. В конце концов брат спросил, не случилось ли чего. «Что с тобой такое?» - сказал он. Я уже собирался сказать, что ничего такого со мной не было, но потом почувствовал, что во мне все перевернулось. Подавляющее, отвратительное чувство. Никогда ничего подобного не испьтывал и сказать ничего не сумел. Вместо этого я сел на траву и покачал головой. Брат подошел и присел рядом со мной. Я заплакал. Я не плакал уже много лет. Похоже, брата это удивило.

После прочтения этого фрагмента у читателя скорее всего должна появиться эмоция сочувственной иронии и в то же время сильной эмпатии. Эмоциональное воздействие обеспечивается, в первую очередь, такими словами и фразами, содержащими в семантике коннотации гнева, плача, растерянности и 
т.п. Любому человеку невольно становится жаль героя, запутавшегося в сложной психологической ситуации.

Третий контекст - это описание безуспешной попытки главного героя наладить контакт с собственным братом:

(3) a. Jeg fortalte det til min bror. Han hadde ingen forutsetninger for å forstå det.

б. Я Я поведал об этом брату. Но ему не дано было меня понять.

в. Я Яассказал об этом брату. Предпосылок для понимания этого у него не было.

Переводчики снова намного эмоциональнее описывают ситуацию, используя более пафосно звучащие слова и выражения: «Я поведал об этом брату», «Но ему не дано было меня понять», «Предпосылок для понимания этого у него не было». Второй переводчик дает дословный вариант, что на русском языке звучит несколько «научно».

Чувства, которые автор приписывает персонажу, предстают в тексте как объективно существующие в действительности (диктальные), а чувства, испытываемые автором и выражаемые им, имеют субъективную окраску (модальные). В целостном тексте гармонически переплетаются диктально-эмотивные смыслы (уровень персонажей) и модально-эмотивные смыслы (уровень авторского сознания), совокупность которых и составляет ядро эмотивного содержания текста.

В связи с этим при относительно безграничном многообразии текстовых эмотивных смыслов Бабенко \& Казарин (2005) предлагают выделить две типологических разновидности: эмотивные смыслы, включенные в структуру образа персонажа, и эмотивные смыслы, включенные в структуру образа автора. Такой подход весьма полезен и для целей переводческого анализа. В нашей статье мы ограничимся эмотивными смыслами, составляющими структуру образа персонажа.

Персонаж относится к разряду основных содержательных универсалий текста и, по мнению В. А. Кухаренко, даже возглавляет систему текстовых универсалий. В связи с этим эмотивные смыслы, включаемые в его содержательную структуру, обладают особой информативной значимостью в тексте (Кухаренко 1974).

Эмоции персонажа изображаются как особая психическая реальность. Совокупность эмоций в тексте - своеобразное динамическое множество, изменяющееся по мере развития сюжета, отражающее внутренний мир персонажа в различных обстоятельствах, в отношениях с другими персонажами (Бабенко \& Казарин 2005, 123). 


\section{[3.2] Классификация эмотивных смыслов}

Эмотивные смыслы, включаемые в структуру персонажа, неравноценны по значимости в тексте, имеют разную функциональную направленность в создании образа литературного героя. В связи с этим Бабенко \& Казарин (2005) считают нужным выделить следующие их типологические разновидности: интерпретационно-характерологические, эмоционально-жестовые и эмоционально-оценочные.

Интерпретационно-характерологические эмотивные смыслы помогают осуществлять интерпретацию с позиции автора текста, воссоздающего на страницах произведения свой вариант эмоций человека. Индивидуально-авторская картина эмоций воплощается прежде всего в эмоциональном портрете персонажа. В романе Э. Лу особенно выпукло представлена неудовлетворенность главного героя своей жизнью.

Интерпретационно-характерологические эмотивные смыслы - это основные эмотивные смыслы в структуре образа персонажа, без них не может быть образа персонажа. Они олицетворяют скрытое от глаз состояние его души. Большим мастером воплощения эмотивных смыслов этого рода можно назвать Л. Н. Толстого.

Отображение в семантике персонажейэмоций как реактивно-ситуативных и как квалификативных, характеризующих, связано с особенностями психологии личности, в частности с двумя важнейшими ее характеристиками жизненной доминантой и ситуационной доминантой (Караулов 1987, 37). Интерпретационно-характерологические эмотивные смыслы в большей степени тяготеют к экспликации, к обязательной манифестации лексическими средствами.

Семантика интерпретационных эмотивных смыслов может варьироваться в зависимости от форм их воплощения. Фразовые эмотивные смыслы обычно интерпретируются как временные реактивные, т.е. как одномоментные отклики на ситуацию. Общетекстовые эмотивные смыслы отражают доминирующее в жизни персонажа эмоциональное состояние. Подобное состояние также может быть реактивным, но его отличие от предыдущих - длительность, продолжительность. Доминантное эмоциональное состояние может интерпретироваться и как постоянное сущностное свойство персонажа, как его характерологическая особенность.

В романе «Наивно. Супер» Эрленд Лу тщательно анализирует доминирующее в эмоциональной жизни персонажа чувство некой зависти, неудовлетворенности собой, которое одновременно является и вполне конкретным, направленным на мир чувством, и обобщенным, вневременным свойством характера персонажа. Так, реакцией главного героя на неудачи в игре в крикет является нервный срыв, вызванный комплексом чувств: растерянностью, боязнью, неуверенностью: 
(4) a. Inn til buskens sentrum. Det var egentlig et fantastisk slag. Jeg bebreider ham det ikke. Jeg bebreider ham det ikke. Jeg hadde uten å tvile gjort det samme selv. Men reaksjonen min. Det var den som overrasket meg.

б. Мой шар так и влетел в кусты, в самую середку. Удар получился на редкость удачным. Я не собираюсь его за это упрекать. Я бы и сам на его месте сделал точно так же. Но вот то, как я на это прореагировал! Я даже сам удивился, потому что не ожидал.

Переводчик в данной ситуации поступает как глубоко сопереживающий персонажу соавтор текста, тем самым заражая читателя уже собственными эмоциями. В оригинале этот эпизод звучит намного сдержаннее. Даже предпоследняя фраза «Men reaksjonen min» на русском языке переведена с восклицательным знаком, что вполне соответствует тому накалу эмоций, которые наблюдаются в русском варианте: «Но вот то, как я на это прореагировал!»

Эмоционально-жестовые эмотивные смыслы символизируют поведением, жестами внутреннюю, скрытую жизнь персонажа. Например, внутренний мир брата становится понятен из следующего описания:

(5) a. Han foretok et par forsiktige testbevegelser. For å forsikre seg om at han var i stand til å maksimere kraften i slaget, og for å unngå å treffe sin egen fot, det mest ydmykende av alt. Så klinket han kulen min inn i den store busken. Han klinket den røde kulen riktig jævlig langt inn i busken.

б. Он сделал несколько легких пробных замахов, убедился, что может вложить в решающий удар всю силу и не попасть при этом молотком по собственной ноге, совершив самый унизительный из всех возможных промахов, и наконец запулил мой шар в самую гущу разросшегося куста.

Опять мы видим, что в переводе текст получился намного «живее», причем трансформации коснулись не только лексики, но и синтаксиса, так как на русском языке вместо коротких суховатых фраз оригинала читаем развернутое сложноподчиненное предложение. Для русскоязычного читателя именно такие предложения имплицируют нервное, неспокойное состояние героя. Не факт, что если бы переводчик сохранил грамматическую структуру, удалось бы передать соответствующую ситуации эмпатему. Однако, весьма эмоциональное норвежское слово jæv lig переведено не столь выразительно. Впрочем, как уже было отмечено, эмоциональность перевода не вызывает сомнений благодаря синтаксическим преобразованиям.

Эмоционально-оценочные смыслы передаются в оценочных высказываниях персонажей, которые можно отнести к высказываниям-экспрессивам. Е. М. Вольф, исследуя функциональную семантику оценочных структур, за- 
метила, что «эмоциональные состояния, которые отражаются в оценочных речевых актах, двояконаправленны: они могут касаться как говорящего, так и собеседника» (Вольф 1985, 175). Вследствие этого в тексте выделяются две типологические разновидности эмотивно-оценочных высказываний.

\section{Эмотивно-оценочные рефлексивы}

Их отличительная особенность - замкнутость в субъекте, направленность на самого говорящего. Коннотативно-эмотивная лексика в большей степени оценочна и в меньшей степени приспособлена для выражения разнообразных эмоциональных тонов. Эрленд Лу активно использует слова этого рода в прямой и несобственно-прямой речи персонажей. Так, подобные номинации широко представлены во внутренней речи главного героя. Как только не характеризует он свое окружение и свои затаенные мысли: har hatet denne busken «ненавидел» (куст); feig «трусоватый» (замысел) и др. Употребление слов с негативной оценкой в ситуации автокоммуникации, во-первых, выражает чувства недовольства, раздражения, испытываемые персонажем; во-вторых, подобная откровенная негативная самооценка персонажа еще сильнее обнажает дисгармонию его внутреннего мира, нерешительность, недовольство собой и окружающим миром:

(6) a. Jeg har hatet denne busken så lenge jeg kan huske. Min plan hadde hele tiden vært enkel og ganske feig. Jeg ga meg ikke. Jeg ville komme tilbake. Jeg planla å slå hans kule under bilen. Det var det eneste som holdt meg gående. At han skulle få svi. At kulen hans på en eller annen måte skulle sette seg fast under bilen. At jeg skulle få se ham krype på alle fire, eller på magen, slik at han ble skitten og begynte å banne.

б. Я всю жизнь, сколько себя помню, всегда ненавидел этот куст. Мой замысел был очень простым и в общем-то трусоватым. Но я не сдавался. Я решил, что еще возьму свое и загоню его шар под машину. Только одна мысль и помогала мне держаться: вот сейчас я задам ему жару! Лишь бы его шар застрял под машиной! А я полюбуюсь на то, как он будет ползать на карачках или на брюхе, весь измажется и начнет ругаться.

в. Я ненавидел этот куст всю свою сознательную жизнь. Мой замьсел был все время прост и довольно труслив. Я не сдавался. Я хотел вернуться в игру. Я собирался забить его шар под машину. Это единственное придавало мне силь. Что он поплатится. Что его шар какнибудь застрянет под машиной. Что я увижу, как он ползает на четвереньках или животе, измажется и начнет ругаться.

Здесь переводчик использовал более эмоционально насыщенную лексику: «вот сейчас я задам ему жару!»; «...будет ползать на карачках или на брюхе...». 


\section{Эмотивно-оценочные регулятивы}

Данный тип речевых оценочных высказываний характеризуется ориентацией на собеседника и включает при этом все виды похвал и оскорблений. Основное средство их манифестации - коннотативно-эмотивная лексика, ярче всего обнажающая межличностные отношения. Условия ее бытования - прямая речь персонажей. Обычно эмоционально-оценочные высказывания чаще всего встречаются в повествовании, ориентированном на разговорную речь, ибо эта лексика несет на себе печать разговорности.

Э. Лу отличается именно своей прямотой при изображении внутреннего мира своего персонажа. В текстах этого писателя используется широкий круг эмоционально-оценочных номинаций, активно пополняемый авторскими окказиональными обозначениями:

(7) a. Jeg skulle ta min bror, den jævelen.

б. Уж я покажу братику, сейчас он у меня попляшет, черт его дери!

в. Я покажу моему брату, гаду этакому.

Эмоционально-экспрессивная частица «уж», которая придает большую живость и эмоциональность высказыванию, «сейчас он у меня попляшет», «черт его дери!» - все эти лексические средства передают, пожалуй, даже излишне эмоционально на русском языке кульминационную фазу сражения на крикетном поле.

Подобные высказывания обладают сильной прагматической направленностью. Персонажи, произносящие их, стремятся оказать эмоциональное воздействие на собеседника, заразить его определенными эмоциями. Особенность этих высказываний - сильный перлокутивный эффект. Мотивы использования эмотивно-оценочных регулятивов - самые разные, чаще всего это реакция на поступки других персонажей. Внутренний облик брата, например, обозначается в романе сразу же, при первом появлении, характеризующими прилагательными (ikke ... sympatisk «не ... симпатичный»; men ... ok «но ... нормальный»):

(8) a. Og så har jeg min bror. Han er kanskje ikke like sympatisk som meg, men han er ok.

б. А еще у меня есть брат. Мой брат, может быть, не такой симпатичный, как я, но, в общем, нормальный.

в. Ещё у меня есть брат. Может быть, он не такой симпатичныцй, как я, но, в общем-то, он нормальный.

и усиливается описанием особенностей его поведения: 
(9) a. Jeg kunne se hva han tenkte på. Men jeg visste at han ikke kom til å ta hensyn.

б. Я видел, что он задумывает. Но я уже понимал, что он не собирается меня жалеть.

Переводчик добавил наречие уже, которого нет в оригинале, для большей эмоциональности. Жалеть - более эмоциональный глагол, чем выражения принимать во внимание, учитывать (дословный перевод).

(10) a. Min bror hadde blitt røver og nå lå den røde kulen min under den store busken. Min bror sto naturligvis og lo.

б. Пришел черед брата разбойничать на площадке, и вот уже мой красный шар закатился в гущу разросшегося куста. А братец, конечно, стоит себе и смеется.

в. Мой брат стал разбойником и теперь мой красный шар лежал 6 большом кусте. Мой брат, конечно же, стоял и смеялся.

Разговорно-уменьшительное «братец» с частицей «а» в противительном значении придает фразе на русском языке гораздо более эмоциональное звучание и вызывает большую эмпатию со стороны читателя.

Приведем еще один фрагмент текста, в котором преобладают эмотивные смыслы с негативной семантикой (тревоги, грусти, безысходности, неодобрения):

(11) a. Jeg kunne se at han ble bekymret. Han hadde ikke sett meg slik før. Han sa at det sikkert er tusenvis av mennesker som hver dag møter veggen. De fleste har det kanskje litt tungt en stund, men så går det bedre.

б. Я заметил, что он встревожен. Он еще никогда не видел меня таким. Он сказал, что каждый день тысячи людей, наверное, сталкиваются с тем, когда перед ними словно бы выросла стена. Многим, наверное, бывает от этого тяжело, но потом это проходит.

в. Я заметил, что он забеспокоился. Он раньше меня таким не видел. Он сказал, что наверняка тысячи людей каждый день ощущают безысходность. У большинства дела идут неважно какое-то время, но затем все налаживается.

Как видим, в структуре образа персонажа обнаруживается многообразие эмотивных смыслов. Но внутренняя жизнь персонажа получает эстетическое осмысление только в контексте всего произведения - с учетом всей системы образов персонажей, в свете авторской концепции. Вне этих связей она неполноценна. Как заметил М. М. Бахтин, «изнутри переживаемая жизнь не трагична, не комична, не прекрасна и не возвышенна для самого предметно ее переживающего и для чисто сопереживающего ему; лишь поскольку я вы- 
ступлю за пределы переживающей жизни души, займу твердую позицию вне ее, активно вовлеку ее во внешне значимую плоть, окружу ее трансгредиентными ее предметной направленности ценностями (фон, обстановка как окружение, а не поле действия - кругозор), ее жизнь загорится для меня трагическим светом, станет прекрасной и возвышенной» (Бахтин 1979, 63).

Эмотивные смыслы под влиянием эмоциональной тональности текста воспринимаются целостно. Совокупность эмоциональных тонов текста не производит впечатления случайного, хаотического набора. В тексте все упорядочено, и эмотивные смыслы в том числе. Ключом к этому служит авторская концепция, то, ради чего и создается текст. Именно она определяет иерархию эмотивных смыслов в тексте и определяет доминанту в их многоголосии, тем самым фактически задает общую эмоциональную тональность текста (Бабенко \& Казарин 2005).

Эмоциональная тональность текста создается также неоднократным повторением отдельного стилистического приема, поэтому любой повтор не только средство текстовой связи, но и обязательное условие возникновения эмоциональной тональности, а повторная лексическая номинация - ее сильное и действенное средство, особенно если дублируется лексика эмоций.

Безусловно, лексические единицы, содержащие семы эмотивности разного ранга, оказывают иррадиирующее влияние на содержание текста и его фрагментов. Извлечение из текста эмотивной лексики и рассмотрение ее в изоляции от текста дает лишь приблизительное, самое поверхностное представление о наборе эмотивных смыслов, реализующихся в тексте в целом в плане их однотипности/разнотипности, монотональности/политональности. Исследуя эмоциональную тональность, в первую очередь надо учитывать художественно-эстетическую значимость эмотивных смыслов и только во вторую очередь - частотность лексических показателей этих смыслов. Прямой зависимости между частотностью и тональностью нет, хотя в научной литературе высказывается и противоположное мнение по этому вопросу, а именно что отображение эмоций в художественном тексте осуществляется в первую очередь благодаря использованию эмотивной лексики. Это чрезвычайно сложный процесс, который обусловлен той нагрузкой, которая падает на слово в тексте.

Изображение различных эмоций: недовольства, раздражения, неприязни, унижения, расстройства, а также порой и некоего романтического порыва, стремления к более интересной, насыщенной жизни чрезвычайно широко представлено в рассматриваемом произведении. Если обобщить эмотивную лексику, использующуюся в формировании психологического портрета главного героя, то можно заметить, что она достаточно разнообразна в категориальносемантическом отношении и единообразна по тональности. Автор использует лексику эмоционального состояния, эмоционального жеста, эмоциональ- 
ной характеризации. При сравнении норвежской и русской лексики приходится учитывать многочисленные переводческие трансформации на уровне морфологии и синтаксиса. В этом видны переводческое мастерство и определенная стратегия, ведь иначе переводной текст звучал бы гораздо менее «по-русски».

Рассмотрение целостного эмотивного содержания текста с учетом категории эмоциональной тональности - предпосылка решения проблемы адекватной передачи эмотивных смыслов. Здесь, прежде всего, выделяются эксплицитные и имплицитные способы. Эмотивная оценка в следуюших контекстах осуществляется с позиции главного персонажа и обнаруживается в его внутренней речи:

(12) a. Jeg satt og tenkte at dette måtte være bunnen. Jeg fryktet at jeg var blitt mett av dage, at jeg aldri noen sinne ville kjenne entusiasme igjen.

б. А я подумал, что провалился на самое дно. Мне стало страшно, что вот я уже пресытился днями и ничто больше не вызовет у меня воодушевления.

в. Я сидел и думал, что наверное дальше уже некуда. Я боялся того, что пресытился жизнью, что я вообще никогда больше не испьтаю воодушевления вновь.

Переводчик тонко подмечает эти откровенные всплески эмоций и соответственно передает их на русском языке. Во втором варианте эмоциональность персонажа проявляется еще сильнее. Доминирующим при этом является не косвенный, а прямой способ изображения эмоций, эксплицитное выражение чувства недовольства своей жизнью. Эрленд Лу показывает сложное эмоциональное состояние персонажа, граничащее с глубокой депрессией:

(13) a. Alt forekom meg meningsløst. Helt plutselig. Mitt eget liv, andres liv, dyrs og planters liv, hele verden. Det hang ikke lenger sammen.

б. Для меня все вдруг утратило смысл. Как-то внезапно. Моя жизнь, жизнь других людей, жизнь животных и растений - все, что ни есть в мире. Все распалось на бессвязные кусочки.

в. Все показалось мне бессмысленным. Ни с того, ни с сего. Моя собственная жизнь, жизнь остальных людей, жизнь животных и растений, весь свет. Все утратило взаимосвязь.

Этот комплекс противоречивых чувств подчеркивается и неоднократно анализируется в тексте самим героем, что несомненно порождает эмпатию со стороны читателя. Неоднократный повтор негативных выражений импликативно сигнализирует о неблагополучии, хотя лексический повтор не столь часто представлен в этом романе: 
(14) a. Alt forekom meg meningsløst. Jeg satt og tenkte at dette måtte være bunnen.

б. Для меня все вдруг утратило смысл. А я подумал, что провалился на самое дно.

В. Все показалось мне бессмысленным. Я сидел и думал, что наверное дальше уже некуда.

В художественном тексте сосуществуют различные эмотивные смыслы, что порождает богатство эмотивного содержания текста, его эмоциональное многоголосие. Текстовые эмотивные смыслы передают не только представление автора о мире чувств человека, но и выражают отношение автора к этому миру. В то же время они прагматичны, направлены на эмоциональное «заражение». Эмотивные смыслы неоднородны, и их совокупность являет собой своеобразную иерархию, зависящую от коммуникативной стратегии текста, в котором эмотивно-модальный макрокомпонент, предназначенный для передачи авторских эмотивно-модальных квалификаций и для эмоционального воздействия на читателя, составляет концептуальный стержень эмотивного содержания текста и возвышается над диктальными эмотивными смыслами, обеспечивающими передачу информации о чувствах персонажей (Бабенко \& Казарин 2005, 158). В качестве иллюстрации приведем два контекста, содержащих эмотивную характеризацию брата главного героя:

(15) a. Dette er en av grunnene til at jeg tror at han innerst inne muligens er mindre sympatisk enn meg.

б. Вот этот случай и заставляет меня в глубине души подозревать, что брат, вероятно, менее симпатичная личность, чем я.

в. Это одна из причин того, что я полагаю, что глубоко внутри он менее симпатичен, чем я.

(16) a. Min bror er optimist. Han ville hjelpe.

б. Брат у меня оптимист. Он хотел мне помочь.

в. Мой брат-оптимист. Он хотел помочь.

Здесь содержатся два имплицитно эмотивных контекста. В первом из них прилагательное в отрицательной форме «не такой симпатичный» указывает на эмотивно-характерологическую доминанту внутреннего мира брата главного героя, а во втором «Брат у меня оптимист. Он хотел помочь.», благодаря иронии, наряду с имплицитным обозначением эмоциональных качеств (жесткость, суховатость, излишний прагматизм), является проводником авторского отношения неприязни, неодобрения. Этот способ репрезентации авторских интенций можно отнести к непрямым, косвенно выраженным эмотивно-оценочным смыслам. Например: 
(17) a. Det må ha vært overraskende for min bror. Han beklaget at han hadde vært så rå under spillet.

б. Брат растерялся от неожиданности. Он принялся просить прощения за то, что вел себя так грубо во время игры.

Таким образом, эмоции главного героя переданы в некоторых случаях асимметрично на русском языке: в контекстах, описывающих внутреннее состояние героев, наблюдаются расхождения, как правило, в сторону усиления и разнообразия эмоциональных проявлений, в противоположность приглушенности эмоционального фона в оригинале.

\section{[4] Выводы}

Ведущая семантическая роль в репрезентации эмоций в оригинальных и переводных вариантах принадлежит эмотивной лексике и эмфатическому синтаксису норвежского и русского языков, причем на русском языке эмоциональность передается гораздо более сильными лексическими и синтаксическими средствами, чем в норвежском оригинале.

Эмотивные смыслы, включенные в структуру образа персонажа, функционально подразделяются на интерпретационные (характерологические и изобразительно-жестовые) и эмоционально-оценочные смыслы. Первые интерпретируют с позиции автора эмоциональное состояние персонажа и проявление этого состояния во внешности, жестах, поведении, речи; вторые являются средством эмоциональной оценки персонажа и с позиций автора, и с позиций других персонажей.

Для переводчика весьма важно выделить эмоциогенные контексты, определить эмоциональную доминанту текста, суметь передать эмпатемы оригинального текста средствами переводящего языка.

Доминирующим способом актуализации эмпатемы при переводе с норвежского языка на русский, как правило, является экспликация как метод уточнения смысла той или иной эмпатемы. Однако в некоторых случаях переводчику приходится действовать противоположным способом, т.е. имплицировать информацию, давать лишь намеком подсказку читателю об эмоциональном состоянии главного героя.

В большинстве случаев при переводе норвежской прозы на русский язык удается сохранить и имплицитный смысл оригинала, и его невыраженность. Переводчик Инна Стреблова с достаточно глубоким проникновением в эмоциональный мир автора романа «Наивно. Супер» Эрленда Лу и его главного героя воссоздает средствами русского языка эмотивные смыслы оригинала. 


\section{СПИСОК ЛИТЕРАТУРЫ}

Ананьина, М. А. 2009. Метод импликативного поиска как способ интерпретации текста. Иностранные языки и литература в современном международном образовательном пространстве. Екатеринбург.

Бабенко, Л. Г. \& Ю. В. Казарин. 2005. Лингвистический анализ художественного текста. Теория и практика. Учебник. Практикум. М.

Бахтин, М. М. 1979. Эстетика словесного творчества. М.

Белянин, В. П. 2000. Основы психолингвистической диагностики. (Модели мира в литературе). М.: Тривола.

Болотнова, Н. С. 1992. Коммуникативные универсалии и их лексическое воплощение в художественном тексте. В кн.: Науч. докл. высш. шк. Филол. науки, 4, 75-87.

Вольф, Е. М. 1985. Функциональная семантика оценки. М.

Гусев, В. В. 2005. Актуализация эмпатического образа в переводе художественной литературы. В кн.: Семантические и стилистические аспекты перевода, вып. 506, 8-24. Вестник МГлУ.

Караулов, Ю. Н. 1987. Русский язык и языковая личность. М.

Кашичкин, А. В. 2004. О способах передачи частей имплицитного смысла высказывания при переводе. Перевод: взаимосвязь и взаимовлияние теории и практики. Всероссийский центр переводов. К 80-летию д.ф.н. проф. Вилена Наумовича Комиссарова. М.

Комиссаров, В. Н. 1999. Современное переводоведение. М.: Изд. ЭТС.

Красных, В. В. 1999. Структура коммуникации в свете лингво-когнитивного подхода. Дисс. ... . д-ра филолог. наук.

Кухаренко, В. А. 1974. Типы и средства выражения импликации в английской художественной речи (на материале прозы Э. Хемингуэя). Филологические науки 1. 72-81.

Мезенцева, Т. А. 2006. Лексические средства выражения эмоции удивления в текстах художественных произведений на английском и русском языках. Социокультурные проблемы перевода 7(2). 354-357.

Рецкер, И. Я. 1974. Теория перевода и переводческая практика. М.: Международные отношения. 
Сарджвеладзе, Н. И. 1978. О балансе проекции и интроекции в процессе эмпатического взаимодействия. В кн.: Бессознательное: Природа, функции, методы, исследования, вып. 3, Тбилиси: Мецниереба.

Сорокин, Ю. А. (ред.). 1977. Национально-культурная спещифика речевого поведения. М.: Наука.

Сорокин, Ю. А. 2005. Что мы делаем, когда переводим художественный текст. Вопросы когнитивной лингвистики 1. 44-48.

Фесенко, Т. А. 2005. К проблеме когнитивной модели текста. Филология и кульmypa 32-35.

Флорин, С. 1983. Муки переводческие. Практика перевода. М.: Высшая школа.

АДРеС АВТОРА

Ольга Иннокентьевна Яныгина

Мурманский государственный технический университет

Факультет мировой экономики и международных отношений

Специализированная кафедра иностранных языков

183032 г. Мурманск, ул. Полярные Зори, д. 9, кв. 55

Россия

innokentau@googlemail.com 